\section{Earlywood vessel features in Quercus faginea: relationship between ring width and wood density at two sites in Portugal}

\author{
Vicelina B Sousa ${ }^{(1)}$, José Luís Louzada ${ }^{(2)}$, Helena Pereira ${ }^{(1)}$
}

Wood anatomy holds relevant information for tree development and timber quality (e.g., wood density), which is important for the sustainability of the species. Quercus faginea Lam. (Portuguese or Lusitanian oak) is an autochthonous Mediterranean oak species characterized by a shrinking natural distribution area and use abandonment. We studied the variation of several wood properties and their relationships with the aim of determining and possibly increasing the wood economic value of this species. The anatomical features of earlywood vessels (area, number, frequency and proportion) were investigated in twenty $Q$. faginea trees sampled at two locations within the natural distribution of the species in Portugal. Moreover, we analyzed the variation of vessel features from pith to bark, the radial growth and the wood density to search for patterns and relationships among the analyzed parameters. Mean earlywood vessel area increased with cambial age up to 60-70 years and then leveled off. An inverse pattern was found for the number of vessels per ring beyond that age. Similar radial patterns of all vessel features were found at both sites, and no significant differences in earlywood vessel area were found between sites. The within-tree development of earlywood vessels was age-related, though not influenced by growth. Earlywood vessel features explained the variation of wood density, i.e., wood density of $Q$. faginea was strongly negatively correlated with both mean vessel area and proportion.

Keywords: Quercus faginea, Earlywood Vessels, Wood Density, Ring Width, Variation

\section{Introduction}

Vessel size and distribution throughout a growth ring deeply affect tree physiology and wood utilization. Vessels are the main cell types of the vascular transport system of plants and their importance is higher when the species are under threat of, for example, drought. In fact, the conductive area of vessels seems related to the conductive efficiency and tracks intra-seasonal information (Carlquist 2001, Fonti et al. 2009, 2010). Wood characteristics such as texture (i.e., the wood appearance due to cell morphology and density) are affected by vessel characteristics, thereby the quality of wood products

is also vessel related (Zobel \& Van Buijtenen 1989, Stanzl-Tschegg 2011).

The measurement of vessel features such as area and diameter used to be a very timeconsuming task. However, the current use of microscopy coupled with image analysis makes data acquisition and processing more efficient (Gasson 1985, Sass \& Eckstein 1994, Fonti et al. 2002, Leal et al. 2007). Recently, the number of studies focusing on the variation of vessel features (e.g., with age, growth and site) and their relation to other wood characteristics (e.g., density) has increased, although data is still scanty and results are often species-specific. The main

(1) Centro de Estudos Florestais, Instituto Superior de Agronomia, Universidade de Lisboa, Tapada da Ajuda, 1349-017 Lisboa (Portugal); (2) Departamento Florestal/CITAB, Universidade de Trás-os-Montes e Alto Douro, Quinta de Prados Apartado 202, 5000-911 Vila Real (Portugal)

@ Vicelina B Sousa (vsousa@isa.ulisboa.pt)

Received: May 08, 2014 - Accepted: Dec 31, 2014

Citation: Sousa VB, Louzada JL, Pereira H, 2015. Earlywood vessel features in Quercus faginea: relationship between ring width and wood density at two sites in Portugal. iForest 8: 866-873 [online 2015-04-27] URL: http://www.sisef.it/iforest/contents/?id= ifor1346-008

Communicated by: Francesco Ripullone tendencies in studies on vessel diameter variation have been recently discussed by Anfodillo et al. (2013), with special attention to the relationship between axial conduit widening and tree height.

Vessels are key contributors to wood density, that is inversely proportional to their size and number (Savidge 2003). In oaks, vessel proportion (i.e., the percentage of xylem cross-section occupied by vessels) is one of the major anatomical factors affecting latewood density (Rao et al. 1997) and specific gravity (Zhang \& Zhong 1992). For instance, in Quercus suber vessel size and number were found to contribute significantly to mean ring wood density (Leal et al. 2011).

Contrasting results have been reported so far regarding the variation of vessels with age and tree growth. In Quercus alba the percentage of earlywood vessel area was influenced by the radial position, but not by the ring width (Phelps \& Workman 1994). Earlywood vessel area was larger in fastgrowing than in slow-growing Juglans nigra trees, but no correlation was found between the earlywood vessel area and ring width (Phelps \& Workman 1994). Denne et al. (1999) reported that the total vessel proportion decreased significantly as the ring width increase in Nothofagus nervosa, a diffuse porous hardwood species. In $Q$. suber, the vessel size increased from pith outwards, explaining $32 \%$ of the total variation in wood ring density (Leal et al. 2007, Leal et al. 2011). In Q. rubra, vessel percentage was also found to be correlated with specific gravity, independently of soil types (Hamilton \& Knauss 1986). As for ring porous species, it is generally accepted that latewood width is responsible for the variation in wood ring density, while earlywood width is relatively constant (Chauhan et al. 2006).

Quercus faginea Lam. is a ring porous oak natural occurring mainly in Portugal and Spain. It was more abundant in the XV-XVI centuries when it was used as a valued timber species, while nowadays it is mostly considered for conservation purposes (Capelo \& Catry 2007, Carvalho 1997). Recent studies have shown that vessels represent about 15 $17 \%$ of the xylem tissue in $Q$. faginea, with higher values near the bark, and earlywood vessel diameters also increased radially from pith to bark (Sousa et al. 2014). In this species wood density components (ringwood, earlywood and latewood density) decreased radially and were influenced by tree growth factors (Knapic et al. 2011).

In this work, the distribution pattern of earlywood vessels within the ring and its relationship with the cambial age have been investigated, as well as the relation between vessel parameters and wood density components. To address the above goals, early- 


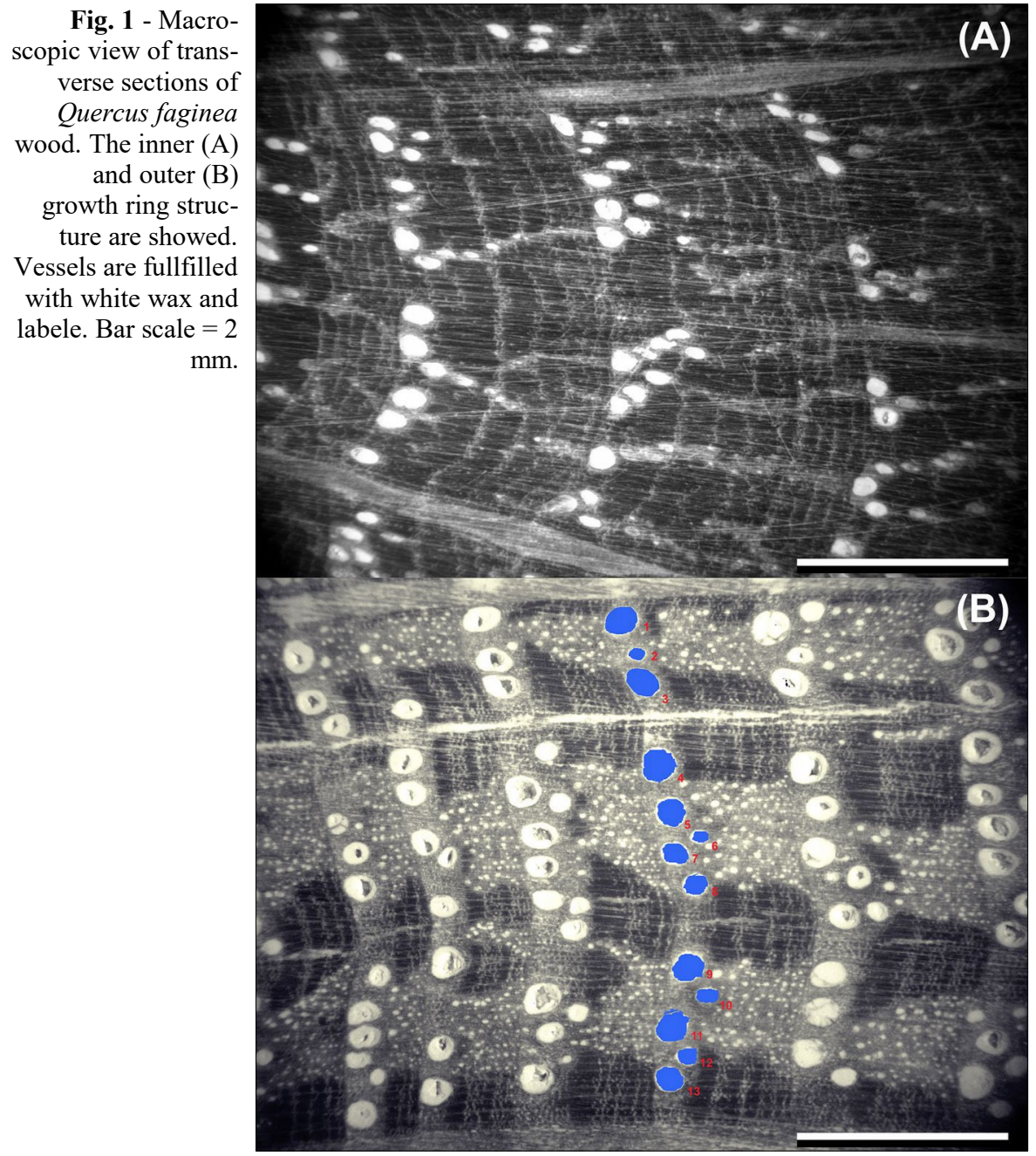

wood vessel features (area, number, frequency and proportion) were analyzed in relation to ring width and wood density in $Q$. faginea trees grown in two sites located in the natural range of the species in Portugal. Sampling included 10 trees with 40 years of age on average and 10 trees with a mean age of 125 years.

\section{Material and methods}

Twenty $Q$. faginea trees were selected in naturally-regenerated, unmanaged forests in Portugal, near Macedo de Cavaleiros (site 1 $-41^{\circ} 30^{\prime} \mathrm{N}, 7^{\circ} 01^{\prime} \mathrm{W}$ ) and Vimeiro (site 2 $\left.39^{\circ} 29^{\prime} \mathrm{N}, 9^{\circ} 01^{\prime} \mathrm{W}\right)$. The climate is Mediterranean tempered by oceanic influence. The mean annual temperature is 12 and $15{ }^{\circ} \mathrm{C}$, and the mean annual rainfall 700 and 890 $\mathrm{mm}$ at site 1 and 2, respectively. The mean summer precipitation (from June to August) is 61 and $70 \mathrm{~mm}$ at site 1 and 2, respectively. Meteorological data available for the most recent 30 years were collected at the meteo stations of Bragança (for site 1) and Vimeiro (for site 2). The soils are classified as orthic dystric and eutric leptosols at site 1 and chromic cambisols at site 2 (Agroconsultores e Coba 1991, IHERA 2001).
Ten dominant or co-dominant trees with no visible signs of decay were harvested at each site. Sampled trees were on average 40 and 125 years-old at the time of sampling in site 1 and 2, respectively. Mean diameter at 1.30 $\mathrm{m}$ above the ground was 21 and $37 \mathrm{~cm}$, and mean tree height was 11 and $15 \mathrm{~m}$ at site 1 and 2, respectively. For each sampled tree, a wood disc was excised at $1.3 \mathrm{~m}$ above the ground level. The wood was analyzed within a radial strip from pith to bark taken in the same compass direction.

Wood density was determined by X-ray microdensitometry and the first results were reported in Knapic et al. (2011). The data on mean ring density, earlywood density, latewood density, heterogeneity index, latewood percentage and ring width were comprehensively analyzed and related with vessel features. The transverse surface of the wood strips used for X-ray measurements was smoothed by fine sanding until pores (vessels) were clearly visible under low magnification. White wax was applied on the surface to fill the vessels, thus allowing a better distinction from the surrounding tissues. A light microscope (Leica DMLA) with $8 \times$ optical magnification $(1$ pixel $=0.00704 \mathrm{~mm})$ was coupled with a digital camera (Leica CCD) to capture sequential images along the radial direction from the pith outwards, by using an image analysis software (Leica Q Win Plus). Images were then converted to grey pixels following the methodology proposed by Leal et al. (2007). Count of earlywood vessels and measurement of their area were performed. After a preliminary analysis of size distribution of all vessels, the minimum area for vessel to be included in further analyses was set to $0.001 \mathrm{~mm}^{2}$, thus discarding smaller vessels. Earlywood was differentiated essentially by the line(s) of large vessels, in contrast to the small vessels region characterizing the latewood.

Mean vessel area (or lumen area of earlywood vessels), vessel proportion (percentage of cross sectional area occupied by the earlywood vessels per growth ring), vessel number (total of earlywood vessels counted by ring) and vessel frequency (number of earlywood vessels per $\mathrm{mm}^{2}$ ) were determined for each annual ring, totaling about 1650 rings. Measurements were carried out within a frame window of approximately $2.3 \mathrm{~mm}$ of tangential width, while the radial dimension varied with each earlywood width, from the inner to the outermost ring. For the determination of vessel frequency and proportion, the total window measurement frame area excluding rays was used.

Terminology follows the IAWA list of microscopic features for hardwood identification (IAWA Committee 1989).

Statistical analysis were performed $(\alpha=$ $0.05)$ using the software package SPSS ${ }^{\circledR}$ ver. 19 (IBM, NY, USA) to analyze the cambial age (i.e., ring number), tree and site effects on earlywood vessel features (mean area, number, density and proportion). Pearson's correlations among ring width and ring density components were determined, and regression curves estimated.

\section{Results}

Variation of earlywood vessel features The ring porous nature of the $Q$. faginea wood was clear both in very narrow growth rings (e.g., at the outermost rings of the older trees) and within the inner growth rings (Fig. 1a, Fig. 1b). For a detailed description of the wood anatomy of the species, see Sousa et al. (2014).

The frequency distribution of vessel area was skewed to the left at both sampling sites, even though more pronounced at site 1 (Fig. 2a, Fig. 2b). Analyzing the above distribution by age intervals, we observed that small vessels with area $\leq 0.020 \mathrm{~mm}^{2}$ are more frequent in the initial years, while above 60 years the distribution is no longer skewed (Fig. 2c, Fig. 2d).

Tab. 1 summarize the observed vessel features at each sampling site. Overall, mean 
Fig. 2 - Frequency distribution of the vessel area at site 1 (a) and site 2 (b), and by age intervals at site 2 , from ring $1^{\text {st }}$ to $30^{\text {th }}(\mathrm{c})$ and from $60^{\text {th }}$ to $100^{\text {th }}(\mathrm{d})$.
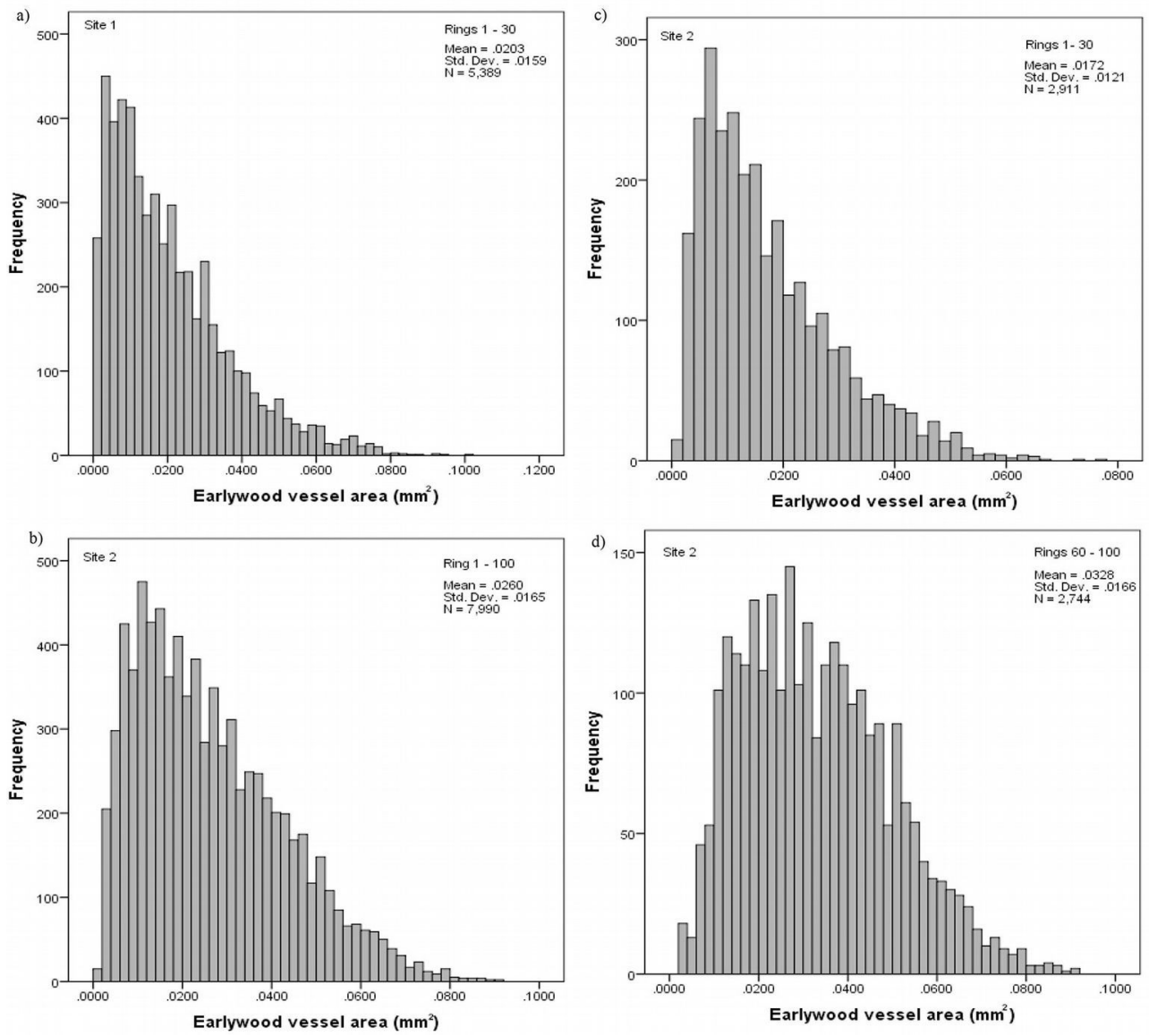

vessel area, vessel frequency and vessel proportion were relatively higher at site 2 as compared with site 1 , while vessel number was lower.

Radial variation of earlywood vessel area showed a large increase in the initial years up to the $60 / 70^{\text {th }}$ rings, with a slight decrease onwards (Fig. 3a). At site 2 the maximum earlywood vessel area reached $0.038 \mathrm{~mm}^{2}$, decreasing to $0.032 \mathrm{~mm}^{2}$ (ca. $200 \mu \mathrm{m}$ tangential diameter) near the bark. The increment of vessel area over the same cambial age period was higher at site 1 . Regression analysis indicated that a second degree polynomial model best predicted the mean vessel area as a function of cambial age $\left(\mathrm{R}^{2}=0.96, \mathrm{p}\right.$ $<0.001$ and $\mathrm{R}^{2}=0.92, \mathrm{p}<0.001$ at site 1 and 2 , respectively - Fig. 3a).

Tab. 1 - Mean value, coefficient of variation (in brackets) and range (lower row) of earlywood vessel area (MVA, $\mathrm{mm}^{2}$ ), vessel number (NV), vessel frequency (VF, $\mathrm{n} \mathrm{mm}^{-2}$ ) and vessel proportion (VP, \%) by tree at site 1 (mean of 30 rings by tree) and site 2 (mean of 100 rings by tree).

\begin{tabular}{ccccc}
\hline Site & MVA & NV & VF & VP \\
\hline 1 & $0.020(78)$ & $18.0(59)$ & $3.1(52)$ & $6.0(67)$ \\
& $0.013-0.034$ & $7.0-19.0$ & $2.0-4.6$ & $1.1-8.0$ \\
\hline 2 & $0.026(78)$ & $8.1(45)$ & $4.2(77)$ & $9.9(74)$ \\
& $0.018-0.030$ & $6.2-10.1$ & $2.1-8.0$ & $5.3-15.9$ \\
\hline
\end{tabular}

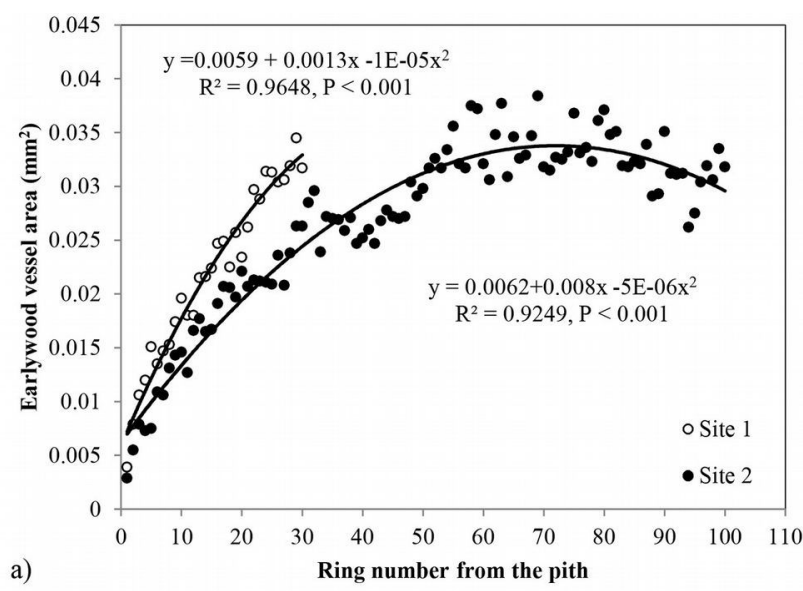

Fig. 3 - Radial variation of (a) mean earlywood vessel area and (b) number of vessels per growth ring in Quercus faginea wood at both sites. Each point represents the mean of 10 trees at each site. 
Fig. 4 - Relationship between the number of earlywood vessels and the mean earlywood vessel area in Quercus faginea wood at: (a) site 1 , within the first 30 rings; (b) site

2 ,within the first 100 rings; and (c) both sites, within the first 30 rings Each point represents the mean value of 10 trees at each site.
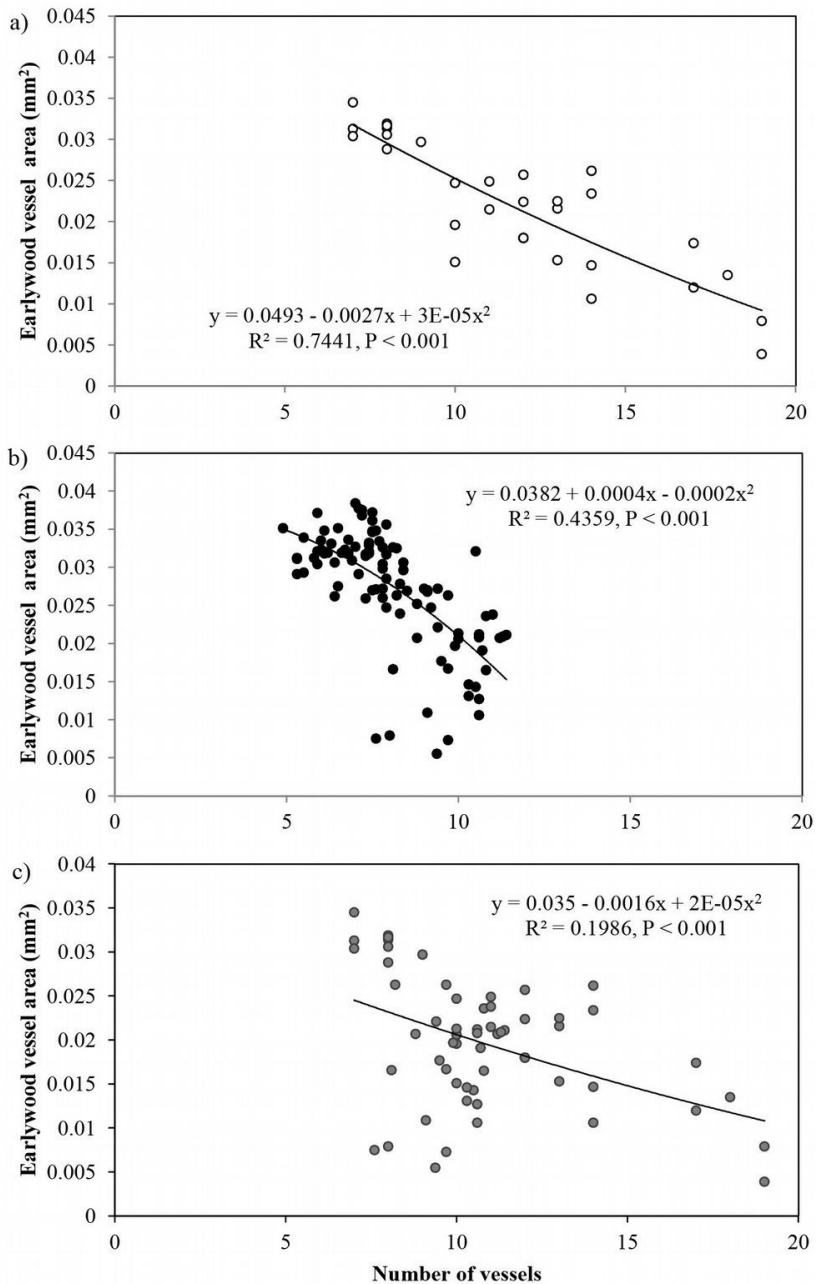

The average vessel number decreased at both sites from pith to bark, though the decrease was more pronounced at site 1 (Fig. $3 b)$. For predicting vessel number based on cambial age, both second degree polynomial and linear regression proved to fit well $\left(\mathrm{R}^{2}=\right.$ $0.72, p<0.001$ and $R^{2}=0.60, p<0.001$ at site 1 and 2, respectively). The relationship between the number of vessels and the mean vessel area per ring fitted both linear and second degree polynomial curves well $\left(\mathrm{R}^{2}=0.74, \mathrm{p}<0.001\right)$ at site 1 (Fig. $\left.4 \mathrm{a}\right)$, while a poorer fitting (though still significant at $\mathrm{p}<0.001$ ) was observed analyzing both sites and site 2 separately (Fig. 4b, Fig. 4c). Indeed, medium to strong negative correlations were found between the number of vessels and mean vessel area (Pearson's $r=-0.162$ at both sites; $r=-0.461$ at site $1 ; r=-0.216$ at site 2 - Tab. 2, Tab. 3, Tab. 4). Although some year-to-year fluctuations occurred, no specific trends of variation of vessel frequency with age was observed (Fig. 5).

Vessel proportion showed an increase with age from the pith up to the $70^{\text {th }}$ ring, with a maximum of $18.4 \%$ and then a slight decrease towards the bark (Fig. 6). This radial pattern was similar to that observed for the mean vessel area (Fig. 3a).

The proportion of vessels was related to ring width, i.e., the highest proportion was found in the narrowest rings and vice versa. Strong correlations were found between ring width and the number of vessels per ring $(0.462<r<0.541)$, vessel frequency $(-0.331$ $<r<-0.411)$ and vessel proportion $(-0.425<$

Tab. 2 - Correlation coefficients between vessel variables, wood density and ring width within the first 30 rings at site 1. (NV): number of vessels; (MVA): mean vessel area; (VD): vessel density per ring width; (VP): vessel proportion per ring width; (MD): mean wood density; (EWD): earlywood density; (LWD): latewood density; (LWP): latewood proportion; (RW): ring width. (**): $\mathrm{p}<0.01$ (2-tailed). Mean values by tree and ring $(n=300,30$ rings $\times 10$ trees $)$.

\begin{tabular}{|c|c|c|c|c|c|c|c|c|c|}
\hline Variable & NV & MVA & VD & VP & MD & EWD & LWD & LWP & $\mathbf{R W}$ \\
\hline NV & 1 & $-0.461^{* *}$ & $0.357^{* *}$ & $-0.233^{* *}$ & $0.157^{* *}$ & 0.071 & $0.16^{* *}$ & 0.119 & $0.486^{* *}$ \\
\hline MVA & - & 1 & $-0.21^{* *}$ & $0.627^{* *}$ & $-0.419^{* *}$ & $-0.395^{* *}$ & $-0.36^{* *}$ & $-0.229^{* *}$ & $-0.225^{* *}$ \\
\hline VD & - & - & 1 & $0.315^{* *}$ & -0.064 & 0.053 & -0.03 & $-0.322^{* *}$ & $-0.411^{* *}$ \\
\hline VP & - & - & - & 1 & $-0.455^{* *}$ & $-0.399^{* *}$ & $-0.39^{* *}$ & $-0.304^{* *}$ & $-0.477^{* *}$ \\
\hline MD & - & - & - & - & 1 & $0.858^{* *}$ & $0.975^{* *}$ & $0.251^{* *}$ & $0.194^{* *}$ \\
\hline EWD & - & - & - & - & - & 1 & $0.791^{* *}$ & -0.1 & 0.04 \\
\hline LWD & - & - & - & - & - & - & 1 & $0.178^{* *}$ & $0.166^{* *}$ \\
\hline LWP & - & - & - & - & - & - & - & 1 & $0.377^{* *}$ \\
\hline RW & - & - & - & - & - & - & - & - & 1 \\
\hline
\end{tabular}

Tab. 3 - Correlation coefficients between vessel variables, wood density and ring width within the first 100 rings common to all trees at site 2. Mean values by tree and ring $(\mathrm{n}=898,100$ rings $\times 10$ trees excluding rings without vessels). $(* *): \mathrm{p}<0.01$ ( 2 -tailed). Labels as in Tab. 2 .

\begin{tabular}{|c|c|c|c|c|c|c|c|c|c|}
\hline Variable & NV & MVA & VD & VP & MD & EWD & LWD & LWP & RW \\
\hline $\mathbf{N V}$ & 1 & $-0.216^{* *}$ & $0.154^{* *}$ & -0.023 & $0.204^{* *}$ & $0.123^{* *}$ & $0.244^{* *}$ & 0.071 & $0.462^{* *}$ \\
\hline MVA & - & 1 & $-0.086^{* *}$ & $0.489^{* *}$ & $-0.322^{* *}$ & $-0.337^{* *}$ & $-0.287^{* *}$ & 0.004 & $-0.174^{* *}$ \\
\hline VD & - & - & 1 & $0.579^{* *}$ & $-0.211^{* *}$ & $-0.135^{* *}$ & $-0.229^{* *}$ & $-0.172^{* *}$ & $-0.391^{* *}$ \\
\hline VP & - & - & - & 1 & $-0.374^{* *}$ & $-0.254^{* *}$ & $-0.383^{* *}$ & $-0.265^{* *}$ & $-0.557^{* *}$ \\
\hline MD & - & - & - & - & 1 & $0.909^{* *}$ & $0.975^{* *}$ & $0.217^{* *}$ & $0.385^{* *}$ \\
\hline EWD & - & - & - & - & - & 1 & $0.841^{* *}$ & -0.022 & $0.19^{* *}$ \\
\hline LWD & - & - & - & - & - & - & 1 & $0.179^{* *}$ & $0.424^{* *}$ \\
\hline LWP & - & - & - & - & - & - & - & 1 & $0.352^{* *}$ \\
\hline RW & - & - & - & - & - & - & - & - & 1 \\
\hline
\end{tabular}


Tab. 4 - Correlation coefficients between vessel variables, wood density and ring width within the common years period (the first 30 rings) at both sites. Mean values by tree and ring $(\mathrm{n}=589,30$ rings $\times 20$ trees excluding rings without vessels). $(* *): \mathrm{p}<0.01$ ( 2 -tailed). Labels as in Tab. 2 .

\begin{tabular}{|c|c|c|c|c|c|c|c|c|c|}
\hline Variable & NV & MVA & VD & VP & MD & EWD & LWD & LWP & RW \\
\hline NV & 1 & $-0.162^{* *}$ & 0.075 & -0.07 & $-0.166^{* *}$ & $-0.228^{* *}$ & $-0.147^{* *}$ & $0.164^{* *}$ & $0.541^{* *}$ \\
\hline MVA & - & 1 & $-0.16^{* *}$ & $0.519^{* *}$ & $-0.449^{* *}$ & $-0.449^{* *}$ & $-0.401^{* *}$ & -0.013 & -0.003 \\
\hline VD & - & - & 1 & $0.462^{* *}$ & -0.063 & 0.008 & -0.084 & $-0.15^{* *}$ & $-0.331^{* *}$ \\
\hline VP & - & - & - & 1 & $-0.367^{* *}$ & $-0.277^{* *}$ & $-0.352^{* *}$ & $-0.228^{* *}$ & $-0.425^{* *}$ \\
\hline MD & - & - & - & - & 1 & $0.895^{* *}$ & $0.978^{* *}$ & 0.044 & -0.074 \\
\hline EWD & - & - & - & - & - & 1 & $0.842^{* *}$ & $-0.242^{* *}$ & $-0.221^{* *}$ \\
\hline LWD & - & - & - & - & - & - & 1 & 0.003 & -0.061 \\
\hline LWP & - & - & - & - & - & - & - & 1 & $0.377^{* *}$ \\
\hline $\mathbf{R W}$ & - & - & - & - & - & - & - & - & 1 \\
\hline
\end{tabular}

\section{$r<-0.557$ - Tab. 2, Tab. 3, Tab. 4).}

The best-fitted models for the prediction of earlywood vessel features based on ring width are presented in Fig. 7. Regardless of site, wider rings showed the higher number of vessels and the lower mean vessel area, vessel frequency and proportion.

\section{Influence of earlywood vessel features on wood density}

Considering the common period of 30 rings in the trees of the two sites, the mean wood density and the earlywood density were inversely correlated with the mean vessel area $(r=-0.449, \mathrm{p}<0.01)$, as well as the

Fig. 5 - Radial profile of earlywood vessel frequency per growth ring in Quercus faginea wood. Each point represents the mean of 10 trees at each site.

Fig. 6 - Radial profile of proportion of earlywood vessels per growth ring in Quercus faginea wood. Each point represents the mean of 10 trees at each site. mean wood density with the vessel proportion per ring $(r=-0.367, \mathrm{p}<0.01)$. The number of vessels was negatively correlated with wood density $(r=-0.166, \mathrm{p}<0.01)$ and earlywood density $(r=-0.228, \mathrm{p}<0.01)$. The correlation of vessel frequency with wood density was not significant (Tab. 4).

Overall, the wood density components (mean density, earlywood and latewood density) were inversely correlated with mean vessel area $(-0.287, \mathrm{P}<0.01<r<-0.449, \mathrm{P}$ $<0.01)$ and vessel proportion $(-0.254, \mathrm{P}<$ $0.01<r<-0.455, \mathrm{P}<0.01$ - Tab. 2, Tab. 3, Tab. 4). The correlations between the wood density components and the number of ves- sels and vessel frequency were positive and weak within each site.

Fig. 8 shows the trend adjustment curves between the wood density and earlywood vessel features.

\section{Discussion}

In this study, the overall frequency distribution of vessel was left-skewed, as previously reported for $Q$. faginea (Villar-Salvador et al. 1997, Corcuera et al. 2004a, Alla \& Camarero 2012), Q. robur and Q. ilex (García-González \& Eckstein 2003, Campelo et al. 2010, Corcuera et al. 2004b). The vessel distribution seems age-related, and the
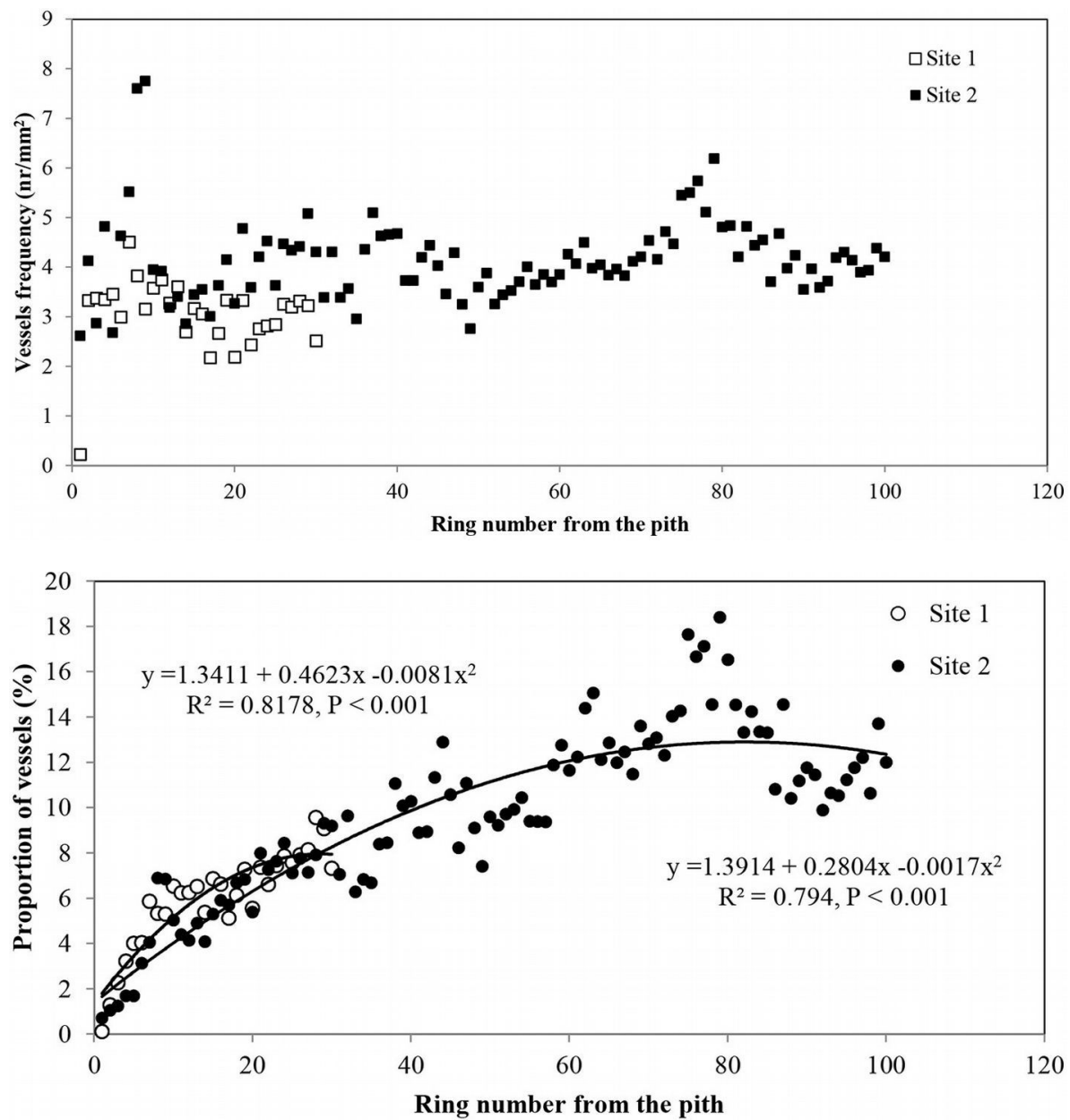

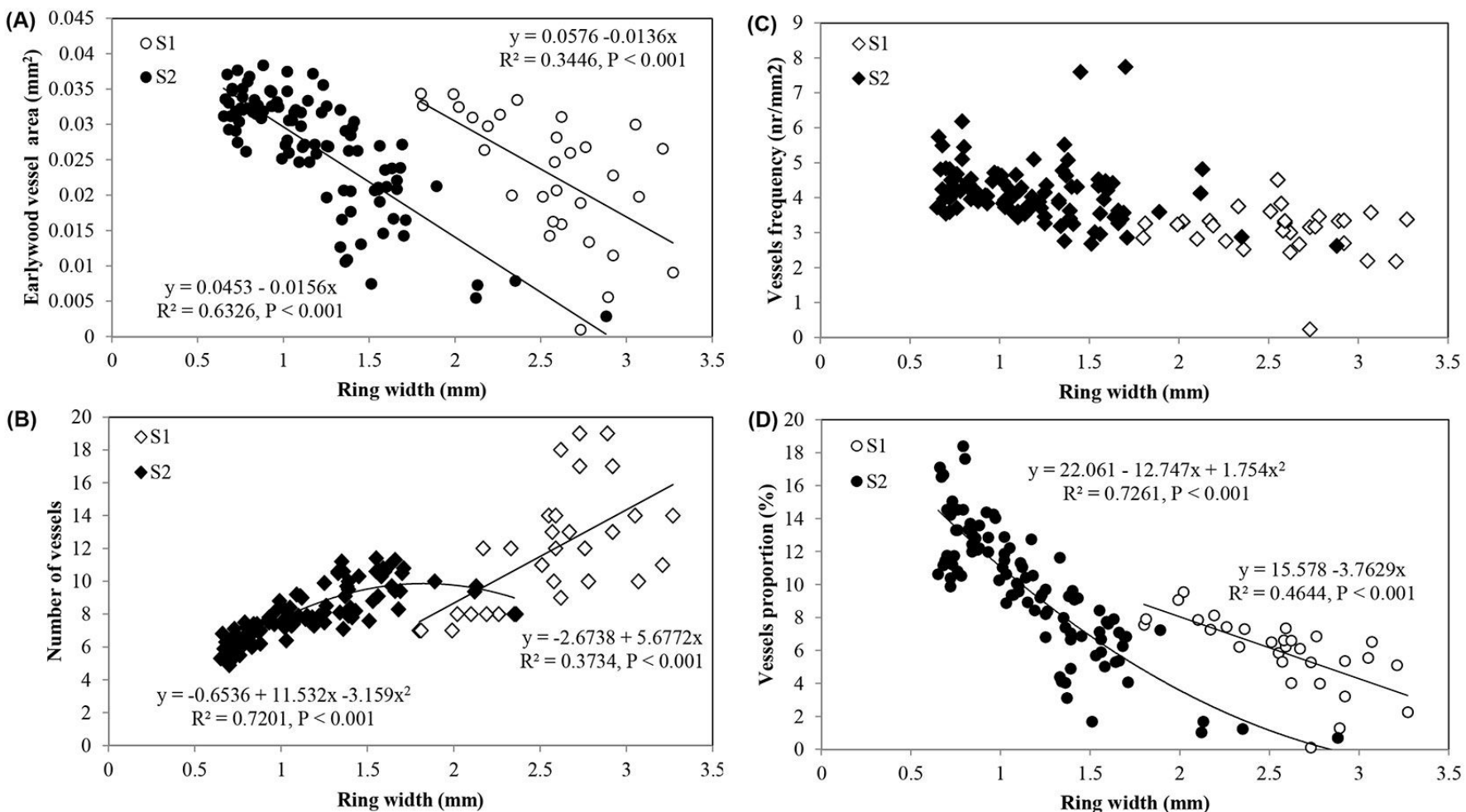

Fig. 7 - Relationships between ring width and: (A) earlywood vessel area; (B) vessels number; (C) vessel frequency; and (D) vessel propor tion in Quercus faginea wood at site $1(\mathrm{~S} 1)$ and $2(\mathrm{~S} 2)$. Each point represents the mean of 10 trees by each site.

large number of small vessels in the initial served in this study is consistent with the was larger or similar as compared with other years seem to be responsible of the above range of values $\left(0.020-0.034 \mathrm{~mm}^{2}\right)$ reported co-occuring evergreen oak species such as distortion. by Alla \& Camarero (2012) for $Q$. faginea. $Q$. coccifera, $Q$. ilex and $Q$. suber, but The mean area of earlywood vessels ob- The area of vessels observed for this species smaller than the vessel size reported for $Q$.
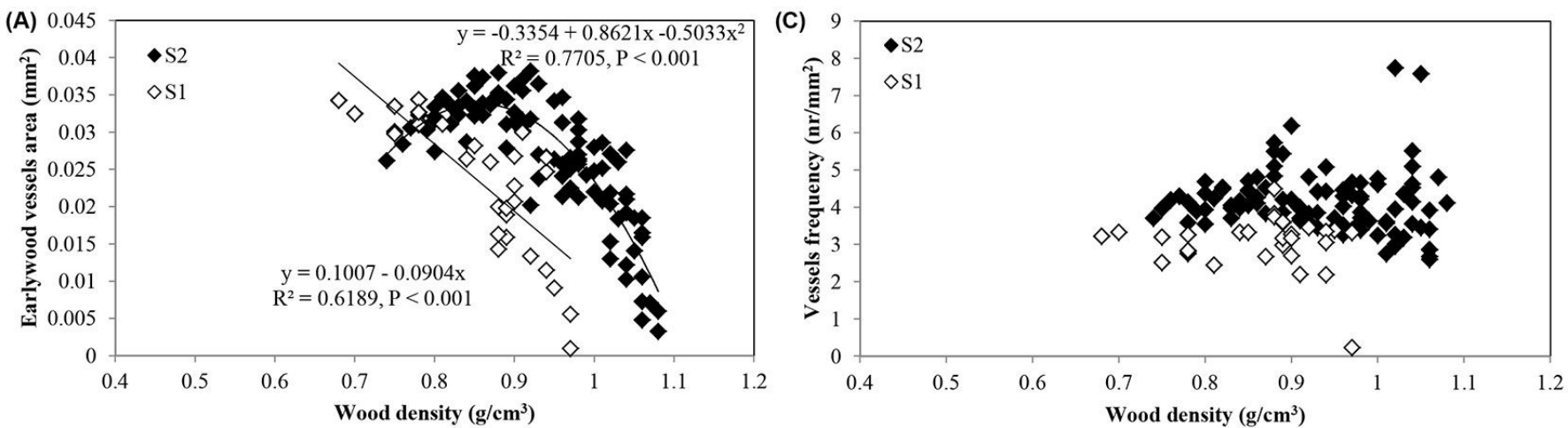

(B)

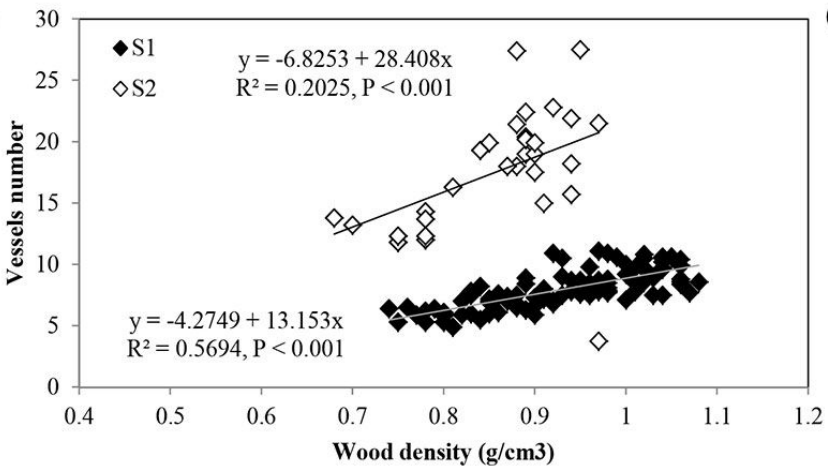

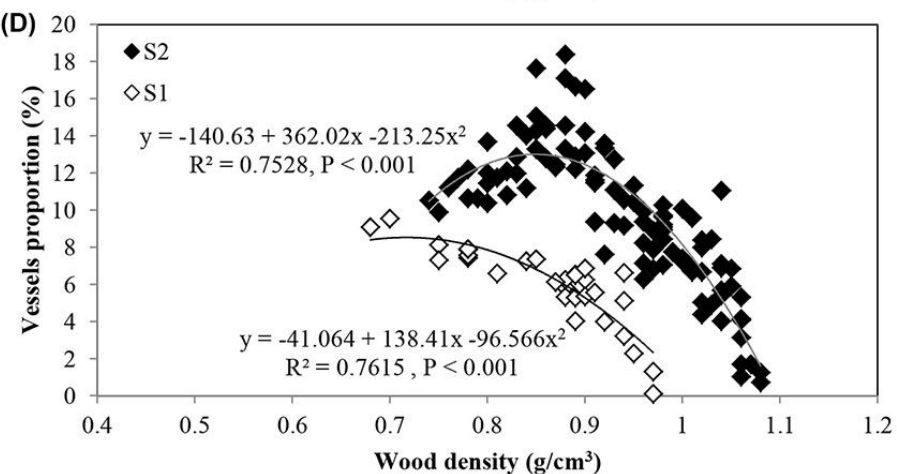

Fig. 8 - Relationships between wood density and; (A) earlywood vessel area; (B) vessels number; (C) vessel frequency; and (D) vessel pro portion in Quercus faginea wood at site 1 (S1) and 2 (S2). Each point represents the mean of 10 trees by each site. 
robur and $Q$. petraea that less frequently cooccur with the portughese oak (Savill 1986, Villar-Salvador et al. 1997, García-González \& Eckstein 2003, Leal et al. 2007, Campelo et al. 2010). It has been reported that vessel features and wood porosity are mainly affected by drought in the Mediterranean area (Cherubini et al. 2003, Baas et al. 1983). In this study, the general climatic conditions are relatively similar in the two sample sites, even though they seemed more favorable at site 2. Nonetheless, vessel features were quite similar between the analyzed sites, as other factors affect drought tolerance of $Q$. faginea, such as the root system (Villar-Salvador et al. 1997).

The increase of earlywood vessel area with cambial age in $Q$. faginea (Fig. 3a) has been also found in other oaks such as $Q$. suber (Leal et al. 2007), Q. garrayana (Lei et al. 1996), Q. macrocarpa (George et al. 2002) and Q. serrata (Tsuchiya \& Furukawa 2009) or in other non-related species such as $\mathrm{No}$ thofagus nervosa (Denne et al. 1999).

The vessel number and vessel frequency are inversely related to average vessel area across species (Preston et al. 2006, Pourtahmasi et al. 2011). Consistently with previous reports (Alla \& Camarero 2012), this was also the case in this study in Q. faginea (Tab. 2, Tab. 3, Tab. 4). The radial profile of the proportion of earlywood vessels of $Q$. faginea (Fig. 6) was similar to that found in $Q$. alba (Phelps \& Workman 1994). Such increase of vessel proportion with ring number is related to the vessel diameter (Richter \& Dallwitz 2000, Sousa et al. 2009). In this study, comparing the same age period between sites the vessel number and their area were higher in samples from site 1, likely due to tree- and/or site-specific factors. In $Q$. $a l b a$, also belonging to the white oaks subgroup as $Q$. faginea, Phelps \& Workman (1994) found that site quality was only expressed in the vessel proportion of trees a younger ages. According to Anfodillo et al. (2013), tree size largely contributes to determine the vessel diameter, meaning that for the same age trees at site 1 seem to be taller showing wider vessels than trees grown at site 2 . The decrease of ring width with age corresponded to a more constant vessel area and number, and to an increase of vessel frequency and proportion. The radial increase of vessel proportion is counterbalanced by a decreasing trend in the width of growth rings (Paul 1963, Knapic et al. 2011, Sousa et al. 2013). The negative correlations between ring width and mean vessel area were stronger for narrower rings as they occurred at site 2 (Fig. 7). In contrast to our results, ring width in Fagus orientalis (semi-ring porous) and $N$. nervosa (diffuse porous) was also negatively correlated with vessel proportion and frequency, although positively correlated with mean vessel area (Denne et al. 1999, Pourtahmasi et al. 2011). Similarly, ring width in $Q$. alba (ring porous) was not correlated to the vessel proportion in earlywood (Phelps \& Workman 1994). However, earlywood vessel features were explained to a lesser extent as function of ring witdh than as a function of age.

The inverse relationship between wood density and earlywood vessel area and proportion in $Q$. faginea (Fig. 8a) was clearly expected. Studies on several angiosperms reported that the average vessel area largely contributed to wood density variation, though a better relationship was found with the vessel proportion (Preston et al. 2006, Rao et al. 1997, Zhang \& Zhong 1992). In $Q$. faginea strong negative correlations were found between wood density and both mean vessel area and proportion. On the contrary, vessel frequency showed only weak correlations with wood density. Similar results were also obtained for $Q$. suber (Leal et al. 2011).

Our results demonstrate that vessel features partly explain the positive correlations between ring width and wood density reported by Knapic et al. (2011), i.e., larger rings with less earlywood vessel area and proportion had higher density, in agreement with the radial decrease tendency of wood density and the weak correlation observed between wood density and latewood proportion in $Q$. faginea.

\section{Conclusions}

The ring porous wood of $Q$. faginea is due to the conspicuous occurrence of earlywood vessels, whose features are age-related. Vessel area increased with cambial age, while their number decreased with age. The radial patterns of the earlywood vessel features were similar between sites.

The earlywood vessel development in $Q$. faginea trees was related to some extent to radial growth. The negative correlation between mean wood density and both mean vessel area and proportion reflected the large impact of earlywood vessels on wood density in this species.

\section{Acknowledgments}

This study was partially supported by the Portuguese Project OAKWOODS (PTDC/ AGR-AAM/69077/2006) from the Portuguese Science Foundation (FCT) within the Fundo Europeu de Desenvolvimento Regional (FEDER) Programme. Forest Research Center (CEF) is a research unit funded by FCT under Pest-/AGR/UI239/2014. The authors would like to thank all the team involved on the project management, execution and fulfillment. Thanks to CITAB Center for the Research and Technology of Agro-Environmental and Biological Sciences team for samples preparation and measurements, and P. Osório (ISA) for special help on vessel data organization. VBS ac- knowledges FCT for a doctoral fellowship.

\section{References}

Agroconsultores e Coba (1991). Carta de solos, Carta de uso actual da terra e Carta de aptidão da terra do Nordeste de Portugal [Soil, actual landuse, and landuse capability maps of Northeast of Portugal]. Vila Real, Portugal. [in Portuguese] Alla AQ, Camarero JJ (2012). Contrasting responses of radial growth and wood anatomy to climate in a Mediterranean ring-porous oak: implications for its future persistence or why the variance matters more than the mean. European Journal of Forest Research 131: 1537-1550. doi: 10.1007/s10342-012-0621-x

Anfodillo T, Petit G, Crivellaro A (2013). Axial conduit widening in woody species: a still neglected anatomical pattern. IAWA Journal 34: 352-364. - doi: 10.1163/22941932-00000030 Baas P, Werker E, Fahn A (1983). Some ecological trends in vessel characters. IAWA Bulletin 4: 141-159. - doi: 10.1163/22941932-90000407

Campelo F, Nabais C, Gutierrez E, Freitas H, García-González I (2010). Vessel features of Quercus ilex L. growing under Mediterranean climate have a better climatic signal than tree-ring width. Trees 24: 463-470. - doi: 10.1007/s00468-0100414-0

Capelo J, Catry F (2007) A distribuição do carvalho-português em Portugal [The portuguese oak distribution in Portugal]. In: "Os carvalhais: um património a conservar” (Silva JS ed). Liga para a Protecção da Natureza, Lisbon, Portugal, pp. 83-94. [in Portuguese]

Carlquist S (2001). Comparative wood anatomy. Systematic ecological and evolutionary aspects of dicotyledon wood. Springer Verlag, New York, USA, pp. 448. [online] URL: http://books.google.com/books?id=iHR7Ui4RT3QC

Carvalho A (1997) Madeiras portuguesas - Estrutura anatómica, propriedades, utilizações [Portuguese woods - anatomy, properties, uses] (vol. II). Direcção-Geral das Florestas, Lisbon, Portugal, pp. 415. [in Portuguese]

Chauhan S, Donnelly R, Huang C-L, Nakada R, Yafang Y, Walker J (2006). Wood quality: in context. In: "Primary Wood Processing. Principles and practice ( $2^{\text {nd }}$ edn)" (Walker JFC ed). Springer, The Netherlands, pp. 121-158. - doi: 10.1007/1-4020-4393-7_5

Cherubini P, Gartner BL, Tognetti R, Braker OU, Schoch W, Innes JL (2003). Identification, measurement and interpretation of tree rings in woody species from mediterranean climates. Biological Reviews 78: 119-148. - doi: 10.1017/S1464 793102006000

Corcuera L, Camarero JJ, Gil-Pelegrin E (2004a). Effects of a severe drought on growth and anatomical properties of Quercus faginea. IAWA Journal 25: 185-204. - doi: 10.1163/2294193290000360

Corcuera L, Camarero JJ, Gil-Pelegrin E (2004b). Effects of a severe drought on Quercus ilex radial growth and xylem anatomy. Trees 18: 83-92. - doi: 10.1007/s00468-003-0284-9

Denne MP, Cahalan CM, Aebisher DP (1999). In- 
fluence of growth rate and cambial age on density of Rauli (Nothofagus nervosa) in relation to vessel lumen areas and numbers. Holzforschung 53: 199-203. - doi: 10.1515/HF.1999.033

Fonti P, Bräker O-U, Giudici F (2002). Relationship between ring shake incidence and earlywood vessel characteristics in chestnut wood. IAWA Journal 23: 287-298. - doi: 10.1163/2294 1932-90000304

Fonti P, Treydet K, Osenstetter S, Frank D, Esper J (2009). Frequency-dependent signals in multicentennial oak vessel data. Palaeogeography, Palaeoclimatology, Palaeoecology 275: 92-99. doi: 10.1016/j.palaeo.2009.02.021

Fonti P, Arx G, García-González I, Eilmann B, Sass-Klaassen U, Gärtner H, Eckstein D (2010). Studying global change through investigation of the plastic responses of xylem anatomy in tree rings. New Phytologist 185 (1): 42-53. - doi: 10.1111/j.1469-8137.2009.03030.x

García-González I, Eckstein D (2003). Climatic signal of earlywood vessels of oak on a maritime site. Trees Physiology 23: 497-504. - doi: 10.109 3/treephys/23.7.497

Gasson P (1985). Automatic measurement of vessel lumen area and diameter with particular reference to pedunculate oak and common beech. IAWA Bulletin 6: 219-237. - doi: 10.1163/22941 932-90000941

George SS, Nielsen E, Conciatori F, Tardif J (2002). Trends in Quercus macrocarpa vessel areas and their implications for tree-ring paleoflood studies. Tree-Ring Research 58: 3-10. [online] URL: http://arizona.openrepository.com/ari zona/handle/10150/26256

Hamilton JR, Knauss SJ (1986). Wood factors affecting the variation in specific gravity of northern red oak (Quercus rubra) associated with soil origin. Forest Ecology and Management 17: 129 136. - doi: 10.1016/0378-1127(86)90105-2

IAWA Committee (1989). IAWA list of microscopic features for hardwood identification. IAWA Bulletin 10: 219-332. - doi: 10.1163/2294193290000496

IHERA (2001). Carta de solos e capacidade de uso do solo. Formato digital [Soil and land use capability maps. CD-ROM]. Instituto de Hidráulica, Engenharia Rural e Ambiente, Ministério da Agricultura, do Desenvolvimento Rural e das Pescas, Lisboa, Portugal. [in Portuguese]

Knapic S, Louzada JL, Pereira H (2011). Variation of wood density components within and between Quercus faginea trees. Canadian Journal and Forest Research 41: 1212-1219. - doi: 10.11 39/x11-038

Leal S, Sousa VB, Pereira H (2007). Radial variation of vessel size and distribution in cork oak wood (Quercus suber L.). Wood Science of Technology 41: 339-350. - doi: 10.1007/s00226006-0112-7

Leal S, Sousa VB, Knapic S, Louzada JL, Pereira H (2011). Vessel size and number are contributors to define wood density in cork oak. European Journal of Forest Research 130: 1023-1029. - doi: 10.1007/s10342-011-0487-3

Lei H, Milota MR, Gartner BL (1996). Betweenand within-tree variation in the anatomy and specific gravity of wood in oregon white oak (Quercus garryana Dougl.). IAWA Journal 17: 445461. - doi: 10.1163/22941932-90000642

Paul BH (1963). The application of silviculture in controlling the specific gravity of wood. Technical Bulletin no. 1288, USDA Forest Service, USA, pp. 97.

Phelps JE, Workman EC (1994). Vessel area studies in white oak (Quercus alba L.). Wood and Fiber Science 26: 315-322.

Pourtahmasi K, Lotfiomaran N, Bräuning A, Parsapajouh D (2011). Tree-ring width and vessel characteristics of oriental beech (Fagus orientalis) along an altitudinal gradient in the Caspian forests, Northern Iran. IAWA Journal 32: 461473. [online] URL: http://booksandjournals.brillonline.com/content/journals/10.1163/2294193290000071

Preston KA, Cornwell WK, DeNoyer JL (2006). Wood density and vessel traits as distinct correlates of ecological strategy in 51 California coast range angiosperms. New Phytologist 170: 807818. - doi: 10.1111/j.1469-8137.2006.01712.x

Rao RV, Aebischer DP, Denne MP (1997). Latewood density in relation to wood fibre diameter, wall thickness, and fibre and vessel percentages in Quercus robur L. IAWA Journal 18: 127-138. - doi: 10.1163/22941932-90001474

Richter HG, Dallwitz MJ (2000). Commercial timbers: descriptions, illustrations, identification, and information retrieval (ver. $4^{\text {th }}$ May 2000). Web site. [online] URL: http://biodiversity.uno. edu/delta/

Sass U, Eckstein D (1994). Preparation of large thin sections and surfaces of wood for automatic image analysis. Holzforschung 48: 117-118. [online] URL: http://www.degruyter.com/view/j/hfs g.1994.48.issue-2/hfsg.1994.48.2.117/hfsg.1994. 48.2.117.xml

Sass U, Eckstein D (1995). The variability of vessel size in beech (Fagus sylvatica L.) and its eco- physiological interpretation. Trees 9: 247-252. doi: 10.1007/BF00202014

Savidge RA (2003). Tree growth and wood quality. In: "Wood quality and its biological basis" (Barnett JR, Jeronimidis G eds). Blackwell Publishing, Oxford, UK, pp. 1-29.

Savill PS (1986). Anatomical characters in the wood of oak (Quercus robur L. and Quercus petraea Liebl.) which predispose trees to shake. Commonweal Forest Revue 65: 109-116. [online] URL: http://www.jstor.org/discover/10.230 7/42608066

Sousa VB, Cardoso S, Pereira H (2009). Structure and anatomical characterization of Lusitanian oak (Quercus faginea Lam.) wood. In: Proceedings of the " 6 " Congresso Florestal Nacional A floresta num mundo globalizado". Ponta Delgada (Portugal) 6-9 Oct 2009. Sociedade Portuguesa de Ciências Florestais, Lisboa, Portugal, pp. 563-571. [in Portuguese]

Sousa VB, Cardoso S, Pereira H (2013). Ring width variation and heartwood development in Quercus faginea. Wood and Fiber Science 45: 110.

Sousa VB, Cardoso S, Pereira H (2014). Age trends in the wood anatomy of Quercus faginea. IAWA Journal 35: 293-306. - doi: 10.1163/229 41932-00000067

Stanzl-Tschegg SE (2011). Wood as a bioinspiring material. Materials Science and Engineering 31: 1174-1183. - doi: 10.1016/j.msec.2010.12.0 01

Tsuchiya R, Furukawa I (2009). Radial variation in the size of axial elements in relation to stem increment in Quercus serrata. IAWA Journal 30: 15-26. - doi: 10.1163/22941932-90000199

Villar-Salvador P, Castro-Díez P, Pérez-Rontomé C, Montserrat-Martí G (1997). Stem xylem features in three Quercus (Fagaceae) species along a climatic gradient in NE Spain. Trees 12: 90-96. doi: 10.1007/PL00009701

Woodcock D (1989). Climate sensitivity of wood anatomical features in a ring-porous oak (Quercus macrocarpa). Canadian Journal of Forest Research 19: 639-966. - doi: 10.1139/x89-100

Zhang SY, Zhong Y (1992). Structure-property relationship of wood in East-liaoning oak. Wood Science of Technology 26: 139-149. - doi: 10.10 07/BF00194469

Zobel BJ, Van Buijtenen JP (1989). Wood variation, its causes and control. Springer-Verlag, Berlin, Germany, pp. 363. [online] URL: http:// www.cabdirect.org/abstracts/19910652155.html 